
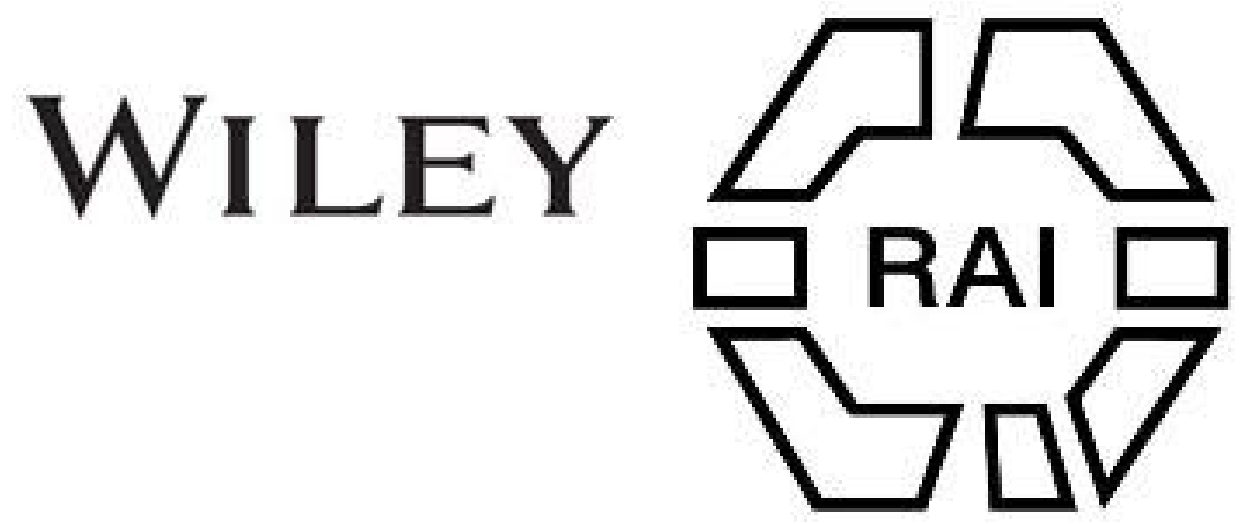

\title{
32. Canadian Indians in 1904.
}

Author(s): David Boyle

Source: Man, Vol. 5 (1905), pp. 55-58

Published by: Royal Anthropological Institute of Great Britain and Ireland

Stable URL: http://www.jstor.org/stable/2788199

Accessed: 27-06-2016 09:04 UTC

Your use of the JSTOR archive indicates your acceptance of the Terms \& Conditions of Use, available at

http://about.jstor.org/terms

JSTOR is a not-for-profit service that helps scholars, researchers, and students discover, use, and build upon a wide range of content in a trusted digital archive. We use information technology and tools to increase productivity and facilitate new forms of scholarship. For more information about JSTOR, please contact support@jstor.org.

Wiley, Royal Anthropological Institute of Great Britain and Ireland are collaborating with JSTOR to digitize, preserve and extend access to Man 
judge," Kusya, in Sıkama, is king (Kun, to arrange), MIbougue is "Father of Life," but the etymology of traditional names does not often yield trustworthy evidence. The Fans, however, are satisfied with these etymologies. The name Nzame, Nyambi, Assyame, Anyam, \&c., is found among all the Buntu peoples whom M. Allégret has observed. The myth is that the being so named once dwelt among them on earth, and left them for the sky because of some offences. Of old he gave them axes and bows. In the same way the Kaitish tribe, reported on by Messis. Spencer and Gillen, believe in Atnatu, a black self-created being in the sky. He expelled his sons, for disobedience, to earth. "Along with them he let down everything that the black fellow has, spears, boomerangs, tomahawks, clubs, . . . and thus he made the Alcheringa in the Kaitish tribe" (Northern Tribes of Central Australia, pp. 498, 499). Mr. Howitt gives many examples of similar "All Fathers."

As among the Kaitish, "their religious ideas have almost no influence on the " ordinary life of the Fans." Nzame is a fading idea, overcome by fetishism and ancestor worship, and, among the Kaitish, the belief in his fatherhood will probably be superseded by the existent belief-that of the Arunta and other tribes-in evolution and re-incarnation. Among the Dieri, Mr. Siebert only found traces, either faint or concealed, of Arawotja, who went about making watercourses, and now lives in the sky." The Dieri, however, unlike the tribes with belief in re-incarnation, hold that they will go to the sky. $\dagger$

Everywhere, I think, we find traces of the All Father belief yielding, among the Kaitish, to the Alcheringa and evolutionary hypotheses : among the Fans, to ancestor worship, and apparently extinct among the Arunta and other northern tribes. But only loug residence and mastery of the languages can enable inquirers to ascertain the truth.

ANDREW LANG.

Canada: Indians.

Boyle.

Canadian Indians in 1904. By David Boyle, Superintendent of the Toronto Museum; Local Correspondent of the Anthropological Institute.

As may readily be supposed by all who do not take it for granted that our aborigines throughout the Doninion are of "oue nation and kindred and people and tongue," and that they are similarly circumstanced, the condition of the Indian varies exceedingly. Those who live near the month of the Mackenzie, those of the prairies, and those of the old provinces, differ nearly as much in many respects as do the inhabitants of Italy from the Scandiuavians, or as the Orcadians from the Majorcaus.

The Report of the Department of Indian Affairs for the year ending June 30th, 1904 , is an illustrated volume of more than 600 pages, and contains, as usual, a multitude of facts and figures digested and undigested relating to the state of the "Agencies" in different portions of the Dominion.

From the sumnary of this information made by Mr. Frank Pedley, Deputy Superintendent of Indian Affairs to the Hon. Clifford Sifton, the Superintendent-General at Ottawa, we learn that in all the provinces, except Ontario, there Las been "substantial progress," although in no case has there been "but small perceptible advance towards " the acquisition of the higher spirit of citizenship," although "the standard of " civilisation already reached bas been fully maintained."

No doubt the authorities are anxious to put the best face on matters by means of the euphemism in the last quotation, but perhaps it should rather read that the spirit of the Indians is now effectually broken, although everything reasonable is being done to maintain the people in something like comfort.

It is reassuring to be informed that "in the younger provinces, among the bands in " process of civilisation where progress is naturally more noticeable, there has not been

* Howitt, Nutive Thibes of South-eastern Australia, pp. 793, 794. † Ibid., p. 800. 
" wanting growth in all the directions which make for independence," and that in the North-west Territories a "stage has been reached at which the able-bodied in the mixed " farming districts have become practically self-supporting."

Many bands, it must be remembered, yet lead as nomadic an existence as the extension of settlements permit, living mainly, if not altogether, on the results of hunting and fishing. When these fail, it is only in the extreme north beyond immediate Government arsistance that real suffering ensues.

Nearer to "the front" great care is taken to prevent unscrupulous traders from selling intoxicants on the reserves, although, notwithstanding so much vigilance, we learn from some of the agency reports that the Indian and the whiskey too often come together.

In proof of the contention that the Indians hold their own in the matter of population the following tables of vital statistics are supplied :-

\begin{tabular}{|c|c|c|c|c|c|c|c|}
\hline \multicolumn{4}{|c|}{-} & \multirow{2}{*}{$\begin{array}{c}\text { BIRTHS, } \\
565\end{array}$} & \multirow{2}{*}{$\begin{array}{c}\text { DeATHS. } \\
450\end{array}$} & \multirow{2}{*}{$\frac{\text { Gain. }}{115}$} & \multirow{2}{*}{$\begin{array}{c}\text { Loss. } \\
-\end{array}$} \\
\hline Ontario & - & - & - & & & & \\
\hline Quebec & - & . & - & 313 & 196 & 117 & - \\
\hline Nova Scotia - & - & - & - & 79 & 63 & 16 & - \\
\hline New Brunswick & - & . & - & 90 & 62 & 28 & - \\
\hline Prince Edward Island & - & - & - & 17 & 13 & 4 & - \\
\hline British Columbia & - & . & - & 778 & 887 & - & 109 \\
\hline Manitoba - & - & - & . & 305 & 263 & 42 & - \\
\hline North-west 'Territories & - & - & - & 495 & 446 & 49 & - \\
\hline \multicolumn{2}{|c|}{ TOTALS } & - & - & 2,642 & 2,380 & 371 & 109 \\
\hline & & & & \multicolumn{2}{|c|}{ POPULATIONS. } & \multirow{2}{*}{ Increase. } & \multirow{2}{*}{ Decrease. } \\
\hline & & & & 1903. & 1904. & & \\
\hline Ontario - & . & . & - & 21,093 & 21,191 & 98 & - \\
\hline Quebec - & - & - & - & 11,066 & 11,149 & 83 & - \\
\hline Nova Scotia & - & - & - & 1,930 & 1,998 & 68 & - \\
\hline New Brunswick & & - & - & 1,699 & 1,694 & - & 5 \\
\hline Prince Edward Isla & & - & - & 301 & 292 & - & 9 \\
\hline British Columbia & & & - & 25,582 & 25,234 & - & 348 \\
\hline Manitoba & - & & - & 6,829 & 6,775 & - & 54 \\
\hline North-west Territories & - & - & - & 17,649 & 17,561 & - & 88 \\
\hline Beyond Treaty limits & - & . & - & 22,084 & 22,084 & - & - \\
\hline TотА & & - & - & 108,233 & 107,978 & 249 & 504 \\
\hline
\end{tabular}

The Deputy Superintendent further on refers to the common helief " that the Indian is a dying race," a belief he calls in question. At most, it is to be feared that the Indians just hold their own in point of number, but it cannot be doubted that miscegenation as well as disease is slowly doing its work. As is pointed out in the report, there is assuredly "t tendency on the part of some bands to disappear, and it is admitted "that there is " prevalent among the Indians a scrofulous condition which predisposes them to mesenteric 
" consumption, and still more to phthisis and other pulmonary, bronchial, and catarrhal " affections," and reference is made to the "first effect of civilization" connected with the change from comparatively open wigwams and teepees to little, overcrowded, dark, and ill"ventilated houses . . . aggravated by unclean habits and promiscuous expectora"tion." These reasons are certainly goor as far as they go, but there is surely some more subtle, deep-lying cause than is here assigned for the decrease or the stagnation in number. It would almost seem as if, not seldom, the very proximity and occasional contact of the white man had something to do with this, just as we know respecting the maleficent effects produced by the appearance of strangers among insular populations, e.g., in St. Kilda, and, as Darwin has pointed out was the case in some Patagonian islands and mainland districts, to say nothing of what occurs among certain breeds of sheep in the south of England.

The most excessive death rate occurred in British Columbia, and is attributed to the crowding together of the people at potlaches, and probably, too, at other ceremonial gathering, but this is just what they have always done. In some districts small-pox seldom quite disappears, but its effects seem to be less fatal than formerly. Other diseases mentioned are whooping-cough, measles, and scarlet fever.

As farmers, our Indians are not great successes. The jump from the nomad to the fixed life was too sudden and too wide. It might have proved advantageous had it been possible to make the Indian first a rancher-a stock raiser-but it is easier to suggest this than to devise a way of making the experiment.

The accompanying table, which might be far worse, will serve to give a good idea of our dusky brothers' standing as agriculturists and stock-raisers :-

\begin{tabular}{|c|c|c|c|c|c|c|c|}
\hline$\longrightarrow$ & - & & & Population. & Acres. & Horned Stock. & Horses. \\
\hline Ontario & - & - & - & 21,191 & 18,006 & 6,558 & 3,632 \\
\hline Quebec & - & - & - & 11,149 & 4,601 & 2,019 & 763 \\
\hline Nova Scotia - & - & - & - & 1,998 & 140 & 296 & 59 \\
\hline New Brunswick & - & - & - & 1,694 & 622 & 48 & 12 \\
\hline Prince Edward Island & - & - & - & 292 & 69 & - & - \\
\hline British Columbia & 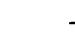 & - & - & 25,234 & 8,675 & 7,575 & 15,276 \\
\hline Manitoba & - & - & - & $6,77 \tilde{5}$ & 1,024 & 2,479 & 646 \\
\hline North-west Territories & - & - & - & 17,561 & 11,961 & 18,85 & $12,24 \pi$ \\
\hline
\end{tabular}

Here and there on the Six Nation and Mississauga Reserves excellent results may be seen, quite equal, indeed, to the best of those achieved by adjoining white settlers. On these reserves, also, are held very creditable agricultural exhibitions, in which fully as much interest is shown as the average fair in any part of Ontario.

In the other provinces less interest is exhibited in farming. The Quebec Indians take to lumbering and some minor industries, while in the north-west more attention is paid to live stock than in any other part of the Dominion. It is mentioned that the Piegans, a band which not long ago refused to take cattle on any consideration, have recently built eleven miles of wire fence as an enclosure for herds.

The farm produce of last year amounted in Ontario to the value of 330,986 dollars ; in Quebec, 115,410 ; in British Columbia, 295,000 ; and in Manitoba and the North-west Territories to 339,676 dollars.

Indian fishing and hunting results give us for the Dominion a total of more than $\$ 1,000,000$, while from other industries a sum exceeding $\$ 600,000$ was earned.

Very few Indians live in our cities and larger towns, and it is even seldom that we find them in villages among white people. They prefer living in communities of their [ 57 ] 
own, and in winter, when not engaged in hunting or in the lumber camps, they make lacrosse stieks, axe and fork handles, whip handles, and split black ash for baskets, while the women knit, do bead work, make fancy baskets, and knick-knacks of various kinds in birch bark ornamented by dyed porcupine quills.

Considerable attention is paid by the Government to the education of the children, but few of them even go beyond the rudiments.

Not many of the old people are fond of education, and in too many cases the teachers cmployed are not of the kind to induce children to attend school.

DAVID BOYLE.

\section{Uganda.}

\section{REVIEWS.}

Uganda and its Peoples. By J. F. Cunningham, F.R.G.S., F.7.S. (Secretary to the Uganda Administration). London : Hutehinson, 1905. Pp. xxix +370 . $26 \times 18 \mathrm{~cm}$. Price $24 \mathrm{~s}$.

Undoubtedly the first impression derived from turning over the leaves of this remarkable book is delight in the beantiful photographic pictures which adorn almost every page. Messrs. Hutchinson have of late brought ont a number of works dealing with Africa and Asia remarkable for their illustrations derived from "nnfaked" photographs; but we question whether any one of them is superior in this respect to the book of which Mr. Cunningham has been both author and illustrator. From its pictures alone the book has great educational value. It illustrates in the main the races of the western part of the Uganda Protectorate, but it gives also a number of pictures of remarkable beasts, birds, and reptiles, and some charming bits of Ugauda scenery. We would especially single out for remark the following illustrations :- "Sese Canoes," p. 81 ; "A Temple of the Domestic God," p. 102. (This illustrates a remarkable incident, a woman making an offering of wild flowers to the shrine of the village ancestral spirit. It is rare that the Negro in his life takes any notice of the glory in colour of his wild flowers); "Baganda Ferrymen," p. 176 ; "An Ant-Eater (Manis)," p. 184 ; "The Demon Crocodile," p. 188 ; "The Inceuse Tree," p. 198 ; " A Water-Lily Creek, Entebbe," p. 207 ; "The Mwesi, or Blacksmith," p. 211 ; "The Flute-player," p. 213 ; "A Sudanese Market Girl,"p. 223 ; "A Devil Hnt," p. 265 ; " Mziba Making Fire," p. 294 ; "Burial of Mtatembwa," p. 297.

A great deal of accurate information is given in this work on the folklore and cnstoms of the indigenous races of the Uganila Protectorate. The former method of burial of the Unyoro kings is described as follows:-

"A circular pit was dug, not more than 5 feet in diameter, and about 12 feet deep. The king's bodyguard seized the first nine Unyoro men they met and threw them alive into the pit. Then the dead body of the king was rolled in bark-cloth, and the skin of a cow, newly killed, wrapped round it and sewn. This bundle was then lowered in the midst of the nine men in the pit. No clay was filled in, but another cow-skin was. stretched tight across the opening and pegged down all round. A covering of grass was then neatly laid over the skin, and the multitude who were present at the funeral set to work at once to build a temple over the grave. A headman was appointed as watcher, and very many of the personal servants of the deceased were appointed to live in the temple and their descendants after them. It was the duty of the surrounding country to see that they were supplied with food.

"Oh, the horrors of that pit! I defy the imagination to picture anything more ghastly. The old Roman laws contained some horrors, but nothing so intensely revolting. Constantine (A.D. 318) enacted that if a father slew his son he should suffer the death of a parricide; that is, to be tied up in a sack with a viper, a cock, and an ape, and be thrown into water and drowned. But this was practically an instantaneous death, and 